\title{
Fault Rocks of the Moine Thrust Zone: a Guide to Their Nomenclature
}

\author{
S. WHITE \\ Geology Dept., Imperial College, London, SW7 2BP
}

(Received April 24, 1981; in final form July 15, 1981)

The aim of this article is to extract from the existing literature a consistent nomenclature that can be used in the description of coherent fault rocks. The nomenclature is dealt with in this paper. Typical microstructures illustrating each is presented in a later paper (White et al., 1982). It will be shown that a simple set of nomenclature can be extracted from the literature, so long as genetic connotations are kept to a minimum. The sequence, with increasing shear strain is country rock-protomylonite-blastomylonite-mylonite-ultramylonite if the rock has a well developed foliation; country rock-protocataclasite-cataclasite-ultracataclasite if it is without a foliation.

It is emphasized that a mylonite is basically a fine-grained schist that has formed within fault zones. It is the association with faulting that distinguishes a mylonite from a fine grain schist.

\section{NOMENCLATURE: OUTLINE OF THE PROBLEM}

The nomenclature of fault rocks, i.e. rocks which are produced during or as a consequence of movements along faults or within fault zones can be rather confusing (see recent summaries by Higgins, 1971; Zeck, 1974). This arises because a large variety of rock types are commonly involved in major fault movements and because fault rocks formed at different levels within the crust, and occasionally the upper mantle, may be juxtaposed if thrust or reverse movements (i.e. uplift) have occurred, In addition, major fault zones normally have a long history of movement. Thus, represented in a zone of fault rocks will be products of movement through different rock types, under different crustal conditions, at varying stresses and strain rates and for different periods of time. Added to these are the effects of inhomogeneous strain within the zone and strain gradients across the zone. It follows that a bewildering array of fault rocks can appear in a single major fault zone. 
The complexity of the likely movement history along the Moine Thrust Zone can be seen in recent papers (Elliot and Johnson, 1979; Coward, 1980; McClay and Coward, 1981). As indicated by these works thrusts nearest the foreland represent shallow movements with those further removed from the foreland representing deeper, inactive zones piggy-backed in by the sole thrust. Thus of the three main thrusts (viz. Sole, Arnabol and Moine) in the Moine Thrust Zone at Eriboll, the Sole Thrust is thought to be the youngest and the Moine the oldest (McClay and Coward, 1981), the latter coming up from the greatest depth. The fault rocks associated with each thrust are likely to reflect this depth difference. To complicate matters further, the spatial distribution of the fault rocks at each thrust may also present a depth profile similar to that which occurs within the fault rock zone associated with the Alpine Fault in New Zealand (Sibson et al., 1979).

\section{TERMINOLOGY}

Up to this point, the term fault rock has been used for rocks developed within fault zones. However, in the recent literature (see Higgins, 1971; Zeck, 1974) it is found that both the terms "mylonites" and "cataclasites" have been used in this general sense. However, the originators of these terms did not intend them to embrace the complete range of fault rocks. Rather, each term was proposed to describe a specific and distinct microstructural type.

\section{MYLONITE AND ASSOCIATED TERMS}

The term mylonite was first used by Lapworth (1885) to describe a fault rock found within the Moine Thrust Zone at Arnabol Hill, Eriboll. Unfortunately, he did not include a sketch or micrograph of the microstructure of his type specimen, largely because he apparently had no microscope. Although Teall (1918) later figured a "typical mylonite" from Arnabol Hill, it would appear that Lapworth's type specimens from Arnabol Hill were subsequently largely neglected. Furthermore, geologists involved with mylonite terminology do not appear to have returned to Lapworth's original paper (see also the comments by Christie, 1960).

In his short article Lapworth (1885) not only introduced the term "mylonite" but also the concept of a microstructural sequence in fault rocks. He records that the mylonite occurred at the thrust plane and passed within a short distance into the following sequence-variegated schists-augen schistsgneissic country rock. He indicated that the sequence is largely microstructural and that the changes are gradational. He gave brief descriptions of each type and these are extracted and repeated below. 


\section{MYLONITE}

Lapworth recorded that "the most intense mechanical metamorphism occurs along the grand dislocation (thrust) planes where the gneisses and pegmatites resting on those planes are crushed, dragged and ground out into a finely laminated schist (mylonite) composed of shattered fragments of the original crystals of the rock set in a cement of secondary quartz, the lamination being defined by minute inosculating lines of chloritic material and secondary crystals of mica." He also stressed that irrespective of the rock type in the area "the resulting mylonite varies in colour and composition according to the material from which it is formed."

Variegated schists which form the transitional zones between the mylonites and the gneiss (Lewisian) are, according to Lapworth, all essentially mylonites in origin and structure. He also refers to them in his paper as "phyllites or mylonites" and again stresses that they "differ locally in composition depending on their parent material."

The augen and crystalline schists he describes as the "more highly crystalline flaggy schists ... to the east of the variegated schists (i.e. further from the thrust) ... appear to be made out of similar material to the variegated schists" and "show the fluxion structure of mylonites." He adds that "in some ... augen schists ... the larger crystals of the original rock from which the schist was formed are still individually recognizable." Lapworth also emphasized that these fault rocks differ from mylonites in that their interstitial paste was crystallized out whereas in mylonites crystallization has only been partial, that is, the matrix of the augen schists is coarser grained. In addition, Lapworth gives the spatial relationship between the rock types- "the mylonites were formed along the thrust planes ..., the augen schists were probably formed in the central parts of the moving system where... weight and pressure forced the rock to yield somewhat like a plastic body. Between these augen schists there appears to be every gradation, on the one hand to the mylonites and on the other to the typical mica-schists."

We see from Lapworth's paper that

i) progressive mylonitisation occurred on approaching the thrust plane; the sequence of rocks being country rock-augen schist-variegated schistmylonite;

ii) all rocks within the Eriboll area underwent the same sequence on approaching a major thrust and

iii) both ductile and brittle processes were involved in producing the sequence.

Lapworth did not regard any one rock as being a type mylonite, it is simply 
a finely laminated schist associated with the thrusting. However, the microstructure he describes and the locality he refers to-gneisses and pegmatites above the thrust (Arnabol) at Arnabol Hill-indicates that he selected a Lewisian mylonite as showing the features characteristic of a mylonite. This is borne out by Teall's paper (1918). Lapworth also thought, incorrectly, that the Lewisian above the Arnabol thrust passed into the Moinian. He did not appreciate that an upper thrust, the Moine Thrust, existed between the two and that another sequence of fault rocks, mainly the crystalline flaggy schists, was present in the Moine Nappe. However, this does not invalidate his microstructural sequence for Teall demonstrated the sequence he described existed solely in the Lewisian above the thrust at Arnabol Hill.

\section{TEALL'S DESCRIPTION OF LAPWORTH'S MYLONITE}

Teall in his description of the locality of the typical mylonite states that "he (Lapworth) led us to Arnabol Hill, showed us Archean gneiss resting almost horizontally on Cambrian quartzite." This description again fits the Arnabol Thrust at Arnabol Hill. The specimen came from the gneiss, described by Lapworth as a "rolled out gneiss." Teall adds that "it could be traced, in a few feet, into rocks which could be identified as portions of the Lewisian gneiss."

Teall pictured the microstructural sequence from mylonite to gneiss but used specimens from different localities. He emphasized that the same progressive sequence occurs in any kind of rock that gets into the mill and lists pegmatites, quartzites and quartzo-feldspathic grits as examples. His choice of different localities then appears to reinforce, just as Lapworth did verbally, the universality of the progressive sequential development of mylonites from various parent rocks along the Moine Thrust Zone. Teall used an even simpler terminology than did Lapworth, viz. mylonite-sheared country rock-country rock. He also stressed the different behaviour between feldspar and quartz. Plagioclase feldspars he states "illustrate the cataclastic effects in a very beautiful manner" showing all stages from faulted twin lamellae into the separation of fragments in a matrix of the fine-grained mylonitic material. Quartz on the other hand "yields more readily to the deforming stresses." It does not break into separate fragments but becomes plastic, loses its distinctive optical characters and takes on "a peculiar kind of crypto-crystalline structure". In other words, the quartz had recrystallized. It is worth noting again that Teall recalls Lapworth referring to the mylonite as "rolled out gneiss." It would appear that the most influential of the early mylonite workers in the Moine Thrust Zone appreciated that crystal plasticity was a part of the mylonitization process and that the process involved a reduction 
in grain size followed by growth of the grains; either the existing grains in the case of some quartz or of new grains formed within the fine-grained matrix in the case of the feldspars.

\section{PROLIFERATION OF TERMS}

Both Lapworth and Teall had devised a relatively simple terminology to describe the progressive mylonitization of a variety of rocks. Yet in the next major paper on Moine mylonite terminology (Christie, 1960), a more complex nomenclature with several new terms is seen. What went wrong?

There appear to be three main answers to the above question. Firstly, as stated previously, little attention was paid to the type area and to Lapworth's paper. Secondly, non-foliated, structureless fault rocks are largely absent in the Arnabol Thrust, in fact within the Moine Thrust Zone, in the Eriboll area. They are more common south of Eriboll (Christie, 1960, 1963) and especially in the Outer Hebrides Fault Zone (Sibson, 1977). Thirdly, experimentalists began to influence geological thinking. The last two points will now be discussed.

Lapworth's term did not cover structureless, non-foliated fault rocks and Grubenmann and Niggli (1924) introduced the term "cataclasite" which they described as an "aphanitic, structureless rock." It should, therefore, be easily recognised both in the field and in thin section from a mylonite which is foliated. Although the term was initially used in this restrictive sense, its use increased until it became synonomous with mylonite and eventually became accepted as a collective term for fault rocks (see Higgins, 1971; Zeck, 1974) following its first usage in this form by Waters and Campbell (1935).

There is no reason why the terms "mylonite" and "cataclasite" should be interposed. They both originated as microstructural terms. This interposition apparently arose when genetic connotations were introduced. It became the view that both were due to cataclasis in spite of Lapworth (1885) and Teall (1918) making clear reference to the role of crystal plastic processes in mylonitization. The reason for the emphasis on cataclasis to the exclusion of crystal plasticity reflected the inability of early experimentalists to plastically deform silicates, especially quartz, in the laboratory (see Griggs and Bell, 1938). It led these authors to postulate that quartz deformed by fracturing into needles which then slid over each other. This postulate had a great influence on geological thinking until the late 1960s. Plasticity of quartz in the laboratory was not achieved until 1964 (Carter et al., 1964). Up until then, authors often referred to recrystallized silicate grains as the products of cataclasis (see Spry, 1969), attempted to relate optical strain features in quartz 
to cataclasis (Anderson, 1945) and generally explained the obvious plasticity of quartz in natural deformation to cataclasis.

A corollary of the acceptance that most silicates deformed cataclastically, was that cataclasis was responsible for grain refinement in all fault rocks derived from silicates. If this is so, then textural differences between the foliated and non-foliated fault rocks must be due to different degrees of grain growth and neomineralization either accompanying or post dating the granulation. For example, extensive post tectonic grain growth was invoked to account for the total absence of any evidence for granulation in some fault rocks. This type of fault rock became a blastomylonite. Mylonites became rocks in which there was a balance between granulation and grain growth and cataclasites those in which there was no grain growth, that is, if a distinction was made between the two terms (Higgins, 1971).

The use of the term "blastomylonite" in the above sense is incorrect, for Sander (1912) used it to describe a fault rock in which neomineralization was advanced and in which grain refinement was not pronounced. As Knopf (1931) pointed out "a blastomylonite is produced by a deformation which is partly ruptural and partly crystalloblastic; not by a rehealing crystallization of a previously mylonitized rock" and added that neomineralization accompanies the process. It is clear that both Knopf and Sander regarded the crystallization (neomineralization) as syntectonic and not post tectonic. Both reflected the belief that all rocks were brittle during a natural deformation. Microstructurally, the term is equivalent to Lapworth's augen schist.

The term "blastomylonite" should not be used to differentiate mylonites with a coarse matrix grain size from those with a fine grain size. Recent studies (Mercier et al., 1977; Twiss, 1977; White, 1979a) have concluded that, for a given mineral, the matrix grain size is largely stress, strain rate and, to a lesser extent, temperature controlled. There is also a mineral dependency which is not well understood. It can be shown empirically that for a given set of deformation conditions a calcite mylonite is coarser grained than a quartz mylonite which is in turn coarser than feldspar. Added to the above is the observed decrease in grain size with increasing strain (White, 1979b; White et al., 1980) which, incidently, accounts for Lapworth being able to distinguish the matrix grains in augen schists but not in the mylonites.

Two other descriptive terms were introduced by early workers and are still commonly used. They are "protomylonite" and "ultramylonite." The first term was introduced by Backlund (1918) to describe a mylonitic rock in which megascopically visible lenticular particles are present and which resembles a conglomerate or arkose on weathered surfaces. The primary structures, e.g. bedding, schistosity, etc, should still be discernible. It is roughly equivalent to Lapworth's augen schist but would appear to describe an early stage in the formation of an augen schist. Staub (1915) used the term "ultramylonite" 
to describe a coherent, streaky fault rock in which all of the original rock has disappeared, i.e. no, or few, porphyroclasts remain. There is no equivalent to this in Lapworth's terminology mainly because the mylonites at Arnabol usually have porphyroclasts.

\section{SELECTED TERMS}

The terms above, based on microstructural grounds, describe the complete development of a mylonite from its parent rock to the stage at which no evidence of the parent remains. Additional terms are pointless. It is recommended that the following sequence is used; country rock-protomyloniteblastomylonite-mylonite-ultramylonite. The cataclasitic sequence to describe structureless, coherent fault rocks is protocataclasite-blastocataclasite-cataclasite-ultracataclasite. Idealised microstructures are sketched in Figure 1.

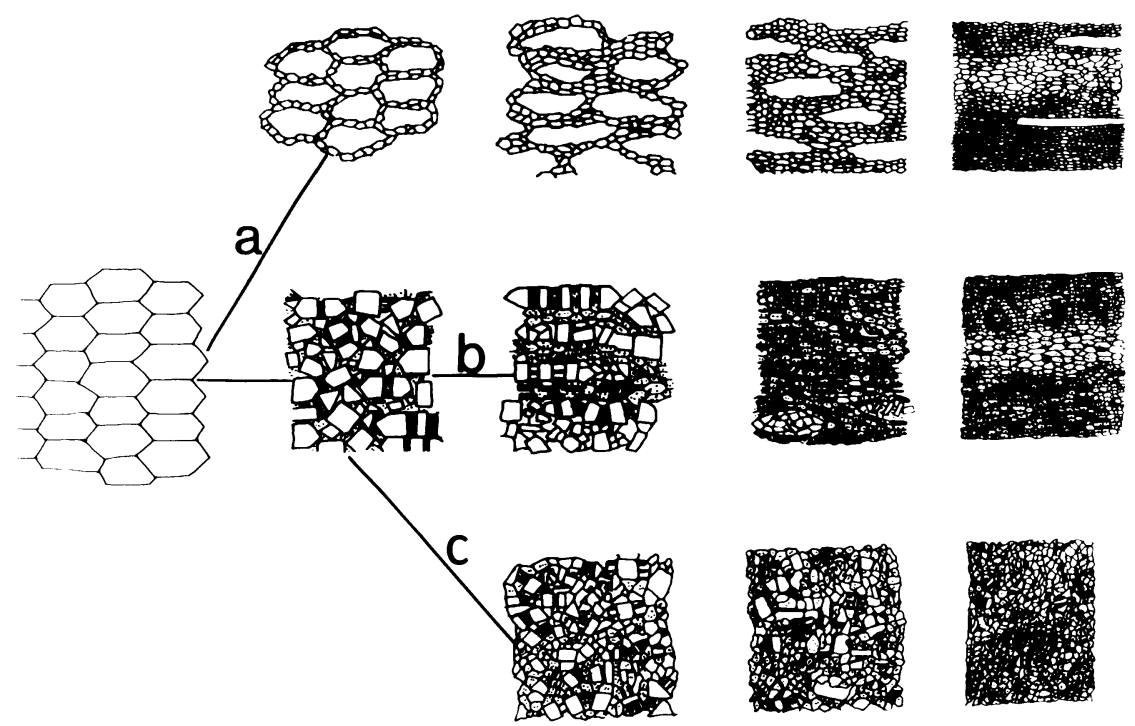

FIGURE 1 A cartoon illustrating the sequential development of fault rock microstructures with increasing shear strain (left to right). Sequence (a) illustrates the microstructures in the sequence protomylonite-blastomylonite-mylonite-ultramylonite in which all stages in the grain refinement were by recrystallization or neomineralization. Sequence (b) illustrates the development of an ultramylonite from a protocataclasite by continuing cataclasis and neomineralization which has produced two different minerals, the one shaded and the other stippled, from the parent rock. The sequence depicted is protocataclasite-blastomylonite-mylonite-ultramylonite. Sequence (c) depicts the progressive development of an ultracataclasite from a protocataclasite, the sequence being blastocataclasite-cataclasite-ultracataclasite. It differs from sequence (b) only in the lack of any foliation forming. 
It should be noted the sequence does not imply that mylonites need have any specific grain size only that there is a general grain size reduction when compared to the parent rock.

The above sequences are similar to those outlined by Spry (1969) and by Sibson (1977) for the Outer Hebrides Thrust fault rocks apart from the insertion of blastomylonite between protomylonite and mylonite and in this aspect follows Christie (1960). A similar insertion has been made in the cataclasite sequence. A comparison between these mylonite terms and those of Lapworth (1885) and Teall (1918) are shown in Table I for the progressive

TABLE I

Comparison of mylonite terms

\begin{tabular}{|c|c|c|c|c|c|}
\hline & $\begin{array}{l}\text { Percentage } \\
\text { fine grained } \\
\text { matrix } \\
\text { (approx.) }\end{array}$ & Lapworth (1885) & Teall (1918) & Sibson (1977) & Above \\
\hline \multirow{6}{*}{ 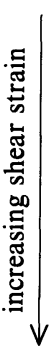 } & 0 & & & & \\
\hline & 25 & Augen schist & $\begin{array}{l}\text { Sheared country } \\
\text { rock }\end{array}$ & Protomylonite & Protomylonite \\
\hline & & & & & blastomylonite \\
\hline & 50 & $\begin{array}{l}\text { (Variegated schist) } \\
\text { Mylonite }\end{array}$ & Mylonite & Mylonite & Mylonite \\
\hline & 75 & & & & \\
\hline & 90 & & & Ultramylonite & Ultramylonite \\
\hline
\end{tabular}

development of a mylonite from a given country rock. The term phyllonite does not appear in the table because, as pointed out by Lapworth, who referred to it as a variegated schist or phyllite, it is essentially a mylonite, albeit a phyllosilicate-rich one.

\section{GENETIC CONNOTATIONS}

The terms used above are all based on microstructures. However, a genetic connotation runs through all of the recent usage of fault rock terms. It is the theme of this contribution that a simple terminology can be arrived at if microstructural criteria are used. Nevertheless, genetic connotations can be accommodated.

Prior to 1973 opinion was that all mylonites were due to cataclastic processes with neomineralization and recrystallization occurring later (e.g. Christie, 1960; Spry, 1969) not necessarily post tectonically but certainly after 
grain refinement. In 1973, Bell and Etheridge (1973) and White (1973) both pointed out that in many mylonites the recrystallization was syntectonic and was responsible for the grain refinement that produced the mylonitic texture. That is, some mylonites are produced by crystal plastic processes, a conclusion reached previously by Teall (1918). The result was an immediate simplification of terminology. Both White (1976) and Sibson (1977) divided coherent fault rocks into two broad categories-cataclasites in which grain refinement was by brittle processes with subsequent deformation by rigid body rotation of the particles, and mylonites in which grain refinement was by recrystallization or neomineralization during a deformation which was dominantly by crystal plastic processes. Both authors regarded cataclasites as structureless and mylonites as foliated. This fits in well with the above microstructural sequences. In cases where the rocks contained hard and soft minerals, e.g. feldspar and quartz, it was the behaviour of the mineral that underwent grain refinement to form a continuous matrix that decided if the rock was a mylonite or cataclasite. The division between the two became more and more diffuse and certainly not recognisable in the field. Both authors (Sibson, 1980; White et al., 1980) came to realise the inadequacy of this genetic-based classification. What term should be used for a fault rock in which the grain refinement was cataclastic and in which, due mainly to neomineralization and pressure solution, subsequent deformation was by crystal plastic processes? The rock will be foliated and from Lapworth's definition it is a mylonite. The microstructural sequence depicting the development of this mylonite is shown in Figure 1 and in the accompanying paper (White et al., 1981). It can be seen that at the ultramylonite stage and perhaps even at the mylonite stage it is microstructurally indistinguishable from a similar fault rock produced entirely by crystal plastic processes. It is proposed that this fault rock should also be referred to as a mylonite because of its foliated nature. Where there is definite evidence that the grain refinement producing the mylonite was by cataclastic processes it can be referred to as a type $c$ mylonite. If recrystallization and neomineralization were the cause of grain refinement then it is a type $r$ mylonite. Distinction between the two types will not normally be possible in the field. It will require thin sections and in many cases a definite conclusion will require the presence of all or most of the microstructural stages. However, it should be easy to recognize a cataclasite from a mylonite (and vice versa) in the field and this should be of assistance when mapping in fault zones.

\section{MYLONITES AND THEIR RELATIONSHIP TO FAULT ZONES}

Lapworth, in his description of mylonites, emphasized that they occurred 
along major dislocation (fault) lines and that it was their relationship to faults that distinguished them from fine-grained schists. It has recently been argued that they can occur along zones of inhomogeneous flattening (Bell, 1981). However, Bell is at odds with Lapworth's original work as such rocks are schists. Furthermore, close examination of Bell's diagrams reveal that his zones of inhomogeneous flattening are fault zones, given the conventional definition of a fault or shear zone, viz. a planar zone across which blocks of rock have been displaced in a direction parallel to the zone (Hobbs $e t$ al., p. 300, 1976). The argument that some flattening occurs across a mylonite zone is not new. It has been discussed by Johnson (1967) who noted a number of field, microstructural and textural features in the Moine mylonites that indicated some flattening. Porphyroclasts in most mylonites show evidence for flattening. Given that mylonite zones are zones of inhomogeneous deformation (White et al., 1980) marked by rocks softer than the bordering country rocks then, if Anderson's (1951) classification is applied to ductile faults, mylonites along thrusts, reverse faults and strike slip faults will experience some flattening.

\section{CONCLUSIONS}

The early literature on Moine Thrust mylonites reveals that a simple set of terms can be used to describe the microstructures of fault rocks. Two broad types are recognised, foliated and non foliated, which are termed the mylonite and cataclasite series respectively. The collective term, fault rock, is used because, as Lapworth pointed out, it is the association of mylonites with faults that distinguishes them from schists.

\section{Acknowledgements}

N.E.R.C. support through grant GR3/3848 is acknowledged. Drs. J. C. White and R. Knipe, D. Evans, M. Norton and M. Drury are thanked for comments.

\section{References}

Anderson, E. M. The Dynamics of Faulting. Oliver \& Boyd, Edinburgh (1975).

Anderson, J. L. Bull. geol. Soc. Am. 56, 409-430 (1945).

Backlund, H. Geol. Foren. Stockholm Forhandl. 40, 101-203 (1918).

Bell, T. H. and Etheridge, M. A. Lithos 6, 337-348 (1973).

Bell, T. H. Tectonophysics 75, 273-296 (1981).

Christie, J. M. Trans. Edin. Geol. Soc. 18, 79-83 (1960).

Christie, J. M. Univ. Calif. Publ. Geol. Sci. 40, 345-419 (1963).

Coward, M. P. J. Struct. Geol. 2, 11-17 (1980).

Elliot, D. and Johnston, M. R. W. Geol. Trans. R. Soc. Edinb. 71, 69-96 (1980).

Griggs, D. and Bell, J. Bull. geol. Soc. Am. 49, 1723-1746 (1938). 
Grubenmann, U. and Niggli, P. Die Gesteinsmetamorphose. Borntraeger, Berlin (1924).

Higgins, M. W. Prof. Pap. U.S. geol. Surv. 687, 1-97 (1971).

Hobbs, B. E., Means, W. D. and Williams, P. F. An outline of Structural Geology. Wiley, New York (1976).

Knopf, E. B. Am. J. Sci. 21, 1-27 (1931).

Johnson, M. R. W. Nature Lond. 213, 246-247 (1967).

Lapworth, C. Nature Lond. 32, 558-559 (1885).

McClay, K. R. and Coward, M. P. In: McClay, K. R. and Price, N. J. (eds.) Thrust and Nappe Tectonics. Geol. Soc. Lond. 241-259 (1981)

Mercier, J. C., Anderson, D. A. and Carter, N. L. Pageoph. 115, 199-226 (1977).

Sander, B. Jahrb. kaiserl konigl geol. Reichsanstalt 62, 219-288 (1912).

Sibson, R. H. J. geol. Soc. Lond. 133, 191-213 (1977).

Sibson, R. H., White, S. H. and Atkinson, B. K. Bull. R. Soc. N.Z. 18, 55-65 (1979).

Spry, A. Metamorphic Textures. Pergamon, Oxford (1969).

Staub, R. Vjschr. naturf. Ges. Zurich 60, 71-91 (1915).

Teall, J. H. H. Proc. Geol. Ass. 29, 1-15 (1918).

Twiss, R. H. Pageogh. 115, 227-244 (1977).

Waters, A. C. and Campbell, C. D. Am. J. Sci. 29, 473-503 (1935).

White, S. Nature Lond. 244, 276-278 (1973).

White, S. Bull. Miner. 102, 210-215 (1979a).

White, S. Contrib. Mineral. Petrol. 70, 193-202 (1979b).

White, S. H., Burrows, S. E., Carreras, J., Shaw, N. D. and Humphreys, F. J. J. Struct. Geol. 2, 175-187 (1980).

White, S. H., Evans, D. and Zhong, D.-L. Textures and Microstructures 5, 33-61 (1982).

Zeck, H. P. Am. J. Sci. 274, 1064-1073 (1974). 